\title{
Perspectives
}

\section{Conceptualizing Integration in CLIL: More Than Just Learning Content and Language}

\section{Sachiko Yasuda Kobe University}

Content and Language Integrated Learning (CLIL) has received a considerable amount of research interest since its inception in the mid-1990s in Europe. The growth thereof has influenced various levels of English language education in Japan. Despite a recent increase in the use of this educational framework, however, a shared understanding of CLIL has yet to emerge. It appears that the term CLIL has acquired some of the characteristics associated with a brand-name that makes it simply appear to be an innovative and forward-looking educational approach. In this paper, I explore the exact nature of CLIL to advocate for the valid application of this pedagogical framework.

1990年代半ばにヨーロッパで始まった「内容言語統合型学習 (Content and Language Integrated Learning、以下CLIL)」は、近年、新しい外国語教育の枠組みとして世界中で注 目を集めており、日本の英語学習環境でも、大学から中高等学校、小学校に至るまで様々 な教育現場で取り入れられ始めている。しかしながら、国内で急速に拡大したCLILとい う概念は、いまや、斬新な外国語指導法をイメージさせる流行語のようになっており、本 来のCLILの目的や理論的背景に対する正確な共通理解が構築できているとは言いがたい 状況である。本稿では、「そもそもなぜ内容と言語の統合なのか」という本質的な問いに 立ち返り、CLILが目指す方向性、その背景にある教育理論について整理・再考し、日本 の英語学習環境への応用可能性について再検討する。

Keywords: Content and Language Integrated Learning (CLIL); inquiry; integration 


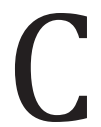

ontent and Language Integrated Learning (CLIL) has received a considerable amount of research interest since its inception in the mid1990s in Europe. Accordingly, the body of internationally accessible research on CLIL is continuously increasing. This growth has influenced the contexts of various levels of EFL education in Japan, not only at university (e.g., Iyobe \& Li, 2013; MacGregor, 2016; Paydon, Birchley, \& McCasland, 2015; Watanabe, Ikeda, \& Izumi, 2011, 2012; Yasuda, 2017), but also at secondary (e.g., Clark, 2013; Ikeda, 2013) and even elementary school levels (e.g., Yamano, 2013a, 2013b). However, as the notion of CLIL has been disseminated among practicing teachers increasingly rapidly in different contexts in Japan, it appears that the term CLIL "has acquired some characteristics of a brand-name" (Dalton-Puffer, Nikula, \& Smit, 2010, p. 3) that makes it simply appear to be an innovative, effective, and forward-looking educational approach that can easily transform from (traditional) teachercentered classrooms to (more innovative) student-centered learning environments. Although no one would disagree with the general CLIL goal of improving students' language learning, there appears to be lack of shared understanding of the exact nature of CLIL: what its theoretical background, rationale, and underlying assumptions are and, most importantly, what it really means to integrate language and content. Therefore, the purpose of this paper is twofold: (a) to address what CLIL is in the European context in which it was originally developed, and (b) to conceptualize the notion of CLIL based on the original framework so as to ensure that educators and practitioners in Japan can develop an accurate understanding of this borrowed framework and apply it to EFL educational contexts here. I will then discuss what I view as central concerns for CLIL, which may need greater attention from the research community as well as from practitioners in Japan.

\section{Theoretical Background and Rationale: What is Meant by CLIL?}

CLIL is a form of education that has spread throughout the world, and particularly in Europe, since the mid-1990s. It draws on earlier models of bilingual education in other countries such as immersion and content-based instruction (Nikula, Dalton-Puffer, Llinates, \& Lorenzo, 2016). Expectations associated with CLIL as an effective educational framework for language learning were fueled by "a radical shift from social monolingualism to multilingualism" (Lorenzo, Casal, \& Moore, 2009, p. 419) and the $2+1$ principle, which is an "agenda to promote language learning to the extent that every European is fluent in at least two languages in addition to their mother 
tongue" (Council of the European Union, 2002, cited in Jaekel, Schurig, Florian, \& Ritter, 2017, p. 632).

CLIL is known as a "dual-focused educational approach" (Marsh, 2002, p. 58 ) that gives equal attention to language and content; it is an educational framework in which subject matter is taught through the medium of a foreign language. CLIL is thus "neither exclusively language learning nor subject learning but rather a fusion of both" (Dalton-Puffer et al., 2010, p. 2). The notion of a fusion of content and language is crucial, given the traditional boundary between content education and language education. Meyer, Coyle, Halbach, Schuck, and Ting (2015) expressed this as follows: "In traditional classrooms, content teachers do not usually focus on the quality of learners' disciplinary literacy and discourse. In language classrooms, subject-specific literacies are considered irrelevant" (p. 41). However, it should be emphasized that in CLIL "language learning and academic achievement are inextricably linked and thus share equal status in terms of educational objectives," (Lyster, 2007, p. 6). In order for a program to be defined as CLIL, therefore, students need to learn language through content and learn content through language rather than learn the language separately from the content; "otherwise this would not be CLIL" (Coyle, Hood, \& Marsh, 2010, p. 33). In this regard, CLIL has the potential to serve as a catalyst for change in both language and content education and plays a role in promoting the interplay between language development and the learning of subject matter.

The crucial point here is that the original concept of what constitutes content in a CLIL context is different from the ways content has traditionally been defined in school curricula in disciplines such as geography, biology, and physics. Because CLIL programs need to consider contextual variables such as teacher availability and language support, a wide selection of content is more appropriate, and therefore, "what exactly is meant by 'content' in CLIL will depend on the context of the learning institution" (Coyle et al., 2010, p. 28). It is thus important to understand the flexibility of CLIL in terms of choice of content.

As a "foreign language enrichment measure packaged into content teaching" (Dalton-Puffer \& Smit, 2013, p. 546), CLIL has gained traction and has become a widespread phenomenon, not only in Europe but all over the world. It has become increasingly common, including in EFL educational contexts, as a result of the increasing prominence English enjoys. However, one may question how and in what ways CLIL can be implemented so as to optimize the fusion between language and content learning or the concurrent teaching of these two components in different educational contexts. 
Researchers and educators have been responding to these challenges, and there is a growing body of research that addresses how to integrate language and content in the most optimal way, as demonstrated below.

\section{Achieving a Balance: How Best to Integrate Language and Content?}

The notion of CLIL as a dual-focused approach signifies that "both language and the subject have a joint role" (Marsh, 2002, p. 58) and that "CLIL advocates a 50:50/Content: Language CLIL equilibrium" (Ting, 2010, p. 3). However, empirical CLIL studies conducted during intact CLIL classes have shown that the way in which integration is carried out varies noticeably: Different models are adopted to suit the needs and expectations of each context, with teachers and educators falling along a continuum ranging from those taking more language-driven approaches to those taking more content-driven ones. The extant research has thus indicated that it is not easy to achieve an exact balance between language and content in CLIL classrooms.

Certain variations are to be expected given that CLIL classrooms are highly contextualized not only at the national level but also at the institutional and/or classroom levels. Although such diversity within CLIL is sometimes criticized for lacking coherence (e.g., Cenoz, Genesee, \& Gorter, 2013), recent studies have shown a general agreement about the "open nature of CLIL as an umbrella term" (Dalton-Puffer et al., 2010, p. 3). This illustrates that CLIL depends on the contingencies of individual contexts and that there is no set formula for CLIL (Coyle et al., 2010; Dalton-Puffer, 2011; Gajo, 2007). This does not necessarily mean, however, that the concept of CLIL lacks theoretical utility. Rather, a high degree of contextualization is essential in research conducted on CLIL so as to explore the many realities of learning a foreign language through content and learning content through a foreign language. Accordingly, Dalton-Puffer and Smit (2013) noted,

The fact must not be overlooked that, like all social science and applied linguistic research, the investigation of CLIL deals with a highly contextualized research object. In our view this has important consequences for the further development of CLIL research so as to ensure a mutually profitable dialogue between CLIL researchers from different parts of the world as well as between researchers and practitioners, who have to act locally. (p. 556) 
Therefore, one may conclude that a situation-sensitive picture emerges in CLIL implementation. However, when employing the term CLIL, one must take into account that CLIL is not just a set of approaches and methods for teaching language, but an educational framework for facilitating the concurrent development of cognitive and language abilities through a fusion of content and language learning (Ikeda, 2016). In that sense, CLIL should be differentiated from similar approaches such as content-based instruction (CBI), where "the subject matter acts as a vehicle for language learning" (Brown \& Bradford, 2017, p. 331); English for Academic Purposes (EAP), where English is taught "with the aim of facilitating learners' study or research in that language" (Hyland \& Hamp-Lyons, 2002, p. 2); and English medium instruction (EMI), or "English-taught degree programs ... predominantly aim at the acquisition of subject knowledge" (Unterberger, 2014, p. 37). Unfortunately, it seems that these terms have often been used synonymously with CLIL by many researchers and teachers in Japan and other parts of Asia (e.g., Clark, 2013; Takano, Kambara, Kedoin, \& Suzuki, 2016; Toh, 2013; Wei, 2013; Yang \& Zhang, 2013).

Subsequently, one may ask how and to what extent the integration of content and language can affect learners' actual development in terms of language proficiency and subject-matter knowledge. In the following section, empirical findings concerning learning outcomes of CLIL are considered.

\section{Research on the Effectiveness of CLIL on Language and Content Learning}

Variation in CLIL as an educational practice suggests that there is also variation in research perspectives on CLIL. For some researchers, integration lies within the scope of second language pedagogies, and accordingly, integration is used for the benefit of learning the language. Other researchers are of the view that integration lies within the scope of subject pedagogies or bilinguals' cognitive development; therefore, integration is used for the benefit of learning the subject.

From the perspective of language pedagogies, CLIL can make classrooms meaning-oriented by affording opportunities for negotiation for meaning, which involves repeating, rephrasing, and restructuring phrases between two or more learners to enable them to understand the meaning of the messages they are communicating (Long, 1996). This leads learners to develop the target language incidentally and naturally while learning the content, transforming declarative knowledge (i.e., metalinguistic knowledge or knowledge about a linguistic form) to procedural knowledge (i.e., 
knowledge about how to perform certain cognitive activities) and in turn, into automatized knowledge (i.e., fluent, spontaneous, and largely effortless behavior; DeKeyser, 2007). Studies have revealed that the areas where a difference between CLIL and regular EFL learners are noticeable include spontaneous oral production (Roquet \& Pérez-Vidal, 2015), greater lexical variation (Agustín Llach \& Jiménez Catalán, 2007), increased lexical richness and sophistication (Lo \& Murphy, 2010; Moreno, 2009), as well as more elaborate and complex structures (Adrián \& Mangado, 2009; Jexenflicker \& Dalton-Puffer, 2010; Villarreal Olaizola \& García Mayo, 2009). In recent years, attempts have been made by a group of scholars in systemic functional linguistics (an approach developed by M.A.K. Halliday, 1994, 1996, 1998 , to analyze language function or how language is used in social contexts to achieve particular goals) to explore how CLIL can enhance learners' use of language in a broader sense by focusing on the following: ideational resources (i.e., language to represent content), interpersonal resources (i.e., language to express register-appropriate styles), and textual resources (i.e., language to express logical relationships in the expression of content; e.g., Llinares, Morton, \& Whittaker, 2012; Meyer et al., 2015; Walker, 2010).

By employing a bilingual education perspective, it has been found that bilingual learners in CLIL environments have an increased metalinguistic awareness compared to monolingual children (Bialystok, 2001, 2007; Bialystok, Peets, \& Moreno, 2014; Hermanto, Moreno, \& Bialystok, 2012). Of great significance is the finding that the influence of an increased metalinguistic awareness may extend beyond the domain of language itself. For instance, studies have shown that bilingual pupils have an advantage in mathematics compared to their monolingual peers because the bilinguals' increased metalinguistic awareness helps them to analyze and understand the "language of math," that is, mathematical concepts (Surmont, Struys, Van den Noort, \& Van de Craen, 2016). Jäppinen (2005) explicated this increased metalinguistic awareness, using the term "analogical reasoning system" (p. 163), which allows learners to make comparisons between the semantic systems of two languages and consequently practice classifying concepts, noticing and creating links between concepts, and hypothesizing diverse things.

Meanwhile, one of the concerns for CLIL involves learning subject matter through a foreign language, which is less perfectly known than learners' L1. Consequently, learning content in CLIL environments could result in reduced subject competence as a result of either imperfect understanding or the fact that teachers may simplify content (Dalton-Puffer, 2011; García 
\& Whittaker, 2010). With respect to content learning, there is a need to seek parity with L1 programs. In other words, the same content objectives should be used to assess the achievement of second language and native speakers alike. Lower standards of achievement should not be established for second language learners (Coyle et al., 2010). However, studies to date have generally shown that the learning of content does not suffer in CLIL environments, and in some cases, CLIL students outperform non-CLIL students even when tested in their L1 (e.g., Van de Craen, Ceuleers, \& Mondt, 2007). As noted previously, this is probably the result of the metalinguistic awareness and analogical reasoning system developed by CLIL students. In other words, linguistic problems may prompt "intensified mental construction activity (through elaborating and relating details and discovering contradictions), resulting in deeper semantic processing and better understanding of curricular concepts" (Dalton-Puffer, 2011, p. 188).

In this vein, the findings of previous studies have generally supported positive outcomes of implementing CLIL. However, most of these studies have been conducted in the European EFL context. Therefore, one may question to what extent the same outcomes can be observed in a different instructional setting such as the Japanese EFL context. In the following section, the current state of CLIL in Japan is discussed.

\section{CLIL in Japan}

In Japan, the idea of teaching a foreign language through content is not new, but has been adopted since the early 1990s under the label of CBI. However, as the concept of CLIL has gained momentum throughout the world, researchers, educators, and other stakeholders in Japan have started paying attention to this framework, using it to name their content- or theme-based language curricula, programs, and classrooms. Accordingly, the term CLIL has been used extensively in various levels of education in Japan since the early 2010s. However, it is important to note that in Japan CLIL is currently used primarily in foreign language (English) classes (and therefore among language teachers and researchers) and not in content classes as originally intended.

Sophia University is in the forefront as a center for CLIL implementation in this country. Makoto Ikeda, an advocate of CLIL, has devoted himself to designing a systematic CLIL curriculum at this university. Sophia University offers a module on CLIL as part of its 2-year master's program in Teaching English to Speakers of Other Languages (Ikeda, Pinner, Mehisto, \& Marsh, 2013). Sophia's CLIL course is theoretically underpinned by the 
framework's original assumptions: “(i) CLIL should be run by content specialists in subject-matter education and (ii) it is timetabled as content lessons, while the target language normally continues as a subject in its own right in the shape of foreign language classes taught by language specialists" (Dalton-Puffer \& Smit, 2013, p. 546). In accordance with this prototypical CLIL form, attempts have been made by other researchers in Japan to develop content-oriented CLIL courses in Japanese universities, such as the 4-year Global Business CLIL course introduced by Paydon et al. (2015) and the one-semester International Economics CLIL course developed by Iyobe and Li (2013).

On the other hand, CLIL approaches have been adopted in language-oriented courses in various Japanese universities, mainly within EAP programs or in classes taught by EAP teachers. One such example is Santos (2013), who described a one-semester CLIL-based academic listening course in which different subjects such as anthropology, history, and sociology are integrated with listening activities to ensure that students can develop both content knowledge and the ability to understand academic lectures. Likewise, Brown (2013) demonstrated how he designed a two-semester sequence of health care English courses for medical students so they can learn medical English vocabulary and doctor-patient communication.

The presence of CLIL can also be found at the secondary level in Japan. For example, Clark (2013) presented a 16-week content-oriented CLIL module embedded within the home economics curriculum at a lower secondary school. The CLIL module was developed through collaboration between a home economics teacher and a language teacher so that a balance between content and language could be achieved. However, Clark reflected on the difficulties she encountered in designing and implementing the course and surmised that the students misconstrued the goal of the course and studied only the language and not the CLIL content. She also outlined the difficulties in measuring gains in content and language knowledge appropriately. Ikeda (2013) detailed a language-driven CLIL course for secondary school students in Japan that was implemented by the teachers who were trained by the researcher in CLIL methodology. The 35-week language-oriented CLIL course was designed so that students gave equal priority to both content (global issues) and language (English knowledge and skills). Interestingly, the year-end evaluation questionnaire revealed that most of the students felt that their learning experience in the CLIL course was denser than in regular English lessons. The CLIL students' written assignments also showed substantial improvement during the year with regard to fluency, lexical di- 
versity, and lexical sophistication. These learning outcomes imply that CLIL could work successfully in Japan if the classes are designed and taught by fully trained CLIL teachers.

CLIL has also begun to emerge as a promising framework for developing elementary school EFL curricula. This is mainly the consequence of the recent reform of the national guidelines for Japanese elementary school English education. Compulsory English education at the elementary school level in Japan was officially instituted in April 2011 by the Japanese Ministry of Education, Culture, Sports, Science and Technology (MEXT). Teachers have since been searching for appropriate methods to teach English to fifth- and sixth-graders. Furthermore, this drive has been fueled by MEXT's decision to make English a formal elementary-school subject starting in 2020. Under these circumstances, attention to CLIL is understandable considering that the guidelines for Japanese elementary school English education advocate that instructions in class should be linked to several other subjects so as to promote elementary school students' interest in English (MEXT, 2009). Yamano (2013a, 2013b) conducted one of the few empirical studies on CLIL implementation at a Japanese elementary school. To identify the effect of 15-week CLIL lessons, Yamano compared two groups of fifth graders: those learning English in CLIL where English was used as a medium for learning subject matter and those in a non-CLIL class in which the target language was taught as the main focus. Her results revealed that CLIL students were more likely to show higher awareness of global issues than their non-CLIL counterparts, and fostering a more positive attitude toward learning English ultimately accelerated vocabulary learning among students.

In general, the literature on CLIL in Japan thus far highlights the possibility that CLIL can play a role in positively influencing the current English language situation in Japan. Many of these CLIL studies have been conducted in university EFL education, and there is a paucity of research on CLIL in secondary and elementary schools, probably because CLIL researchers are generally involved in university education and thus collect data from their own institutions. However, even among university CLIL researchers, a shared understanding of the theoretical underpinnings of CLIL has yet to be established. In particular, it is problematic that the acronym CLIL is often used as a synonym for CBI, EAP, or EMI to name academic English courses. This suggests that CLIL is not understood properly or widely accepted in the applied linguistics circle in Japan. It further stresses the reality that, "if CLIL in Europe is a toddler, CLIL in Japan is a new-born baby" (Ikeda et al., 2013, p. 1). Under these circumstances, where researchers and educators 
conceptualize CLIL in different ways, it is still too early for us to accept generalizations about CLIL outcomes based on the available evidence. To enhance a shared understanding of CLIL and to ensure researchers and educators in this country are able to apply this framework in Japanese EFL contexts, the exact nature of CLIL is reconsidered in the next section with a focus on the fundamental questions: What does it really mean to integrate content and language, and why is integrating content and language necessary in the first place?

\section{Concluding Discussion: Integration as an Essential Tool for "Inquiry"}

As noted earlier, what must not be overlooked in labeling a course as CLIL is that CLIL is not a mere language-learning methodology, but an educational framework for facilitating the concurrent development of cognitive and language abilities through a fusion of content and language learning. I have employed the term "cognitive" because cognitive development plays the key role in promoting learning of all subjects and cannot be separated from content and language learning. Cognition can be developed through experiential learning; this is highlighted by Kolb's (1984) well-known quote: "Learning is the process whereby knowledge is created through the transformation of experience" (p. 38). From this perspective, it can be argued that linking the language with content that engenders students' interests may enrich experiential learning and lead to the enhancement of both language and content knowledge, and beyond that, it may facilitate metalinguistic awareness, motivation, global awareness, and self-confidence. It is for this reason that CLIL professionals in Europe have proposed an array of additional goals of CLIL: "cultural awareness, cognitive advantages, deeper content learning, internationalization, self-confidence, motivation, pluriliteracy, learner autonomy and others" (Dalton-Puffer \& Smit, 2013, p. 547). These extensive goals can also be exemplified by the often-cited 4Cs model of CLIL: content, communication, cognition, and community/culture (Coyle, 2007; Coyle et al., 2010).

In conclusion, it can be argued that the mere integration of meaningful content into the foreign language curriculum is not enough to ensure that the learning experience will be cognitively engaging and motivating to learners. More than just integrating content and language, inquiry should take place as the primary focus in the CLIL classroom because its goal is the concurrent development of content, language knowledge, and beyond: It is not the integration per se, but the context in which the learners are situated that has the largest influence on their increased inquiry. Cammarata (2016) 
succinctly defined the context thus: "the act of questioning and the relentless search for answers to important questions that require deeper forms of thinking" (p. 124).

Takano et al.'s study (2016) offers a suggestion for supporting inquiry-oriented CLIL in the language classroom. The authors proposed that to enhance elementary students' inquiry in CLIL classes, questions such as "How many chairs in this room?" may be cognitively less demanding, whereas questions such as "How many planets in our solar system?" may be more cognitively demanding. This may result in deeper thinking by pupils while helping them to learn the language and the subject matter concurrently. Takano et al. also stressed that expressions such as "It's a piano" and "It's a cube" are the same in terms of sentence structure, but are different cognitively if the former sentence is prompted by a simple picture description question and the latter by a more cognitively difficult math question, requiring pupils to think about a complete shape based on the development of a cube. These example prompts suggest that CLIL classrooms, if guided appropriately, can enhance students' inquiry and, accordingly, lead to the concurrent learning of content and language. Within this paradigm, the integration of language and content in instruction is not simply desirable, but should be viewed as essential, indeed inevitable, to make foreign language education successful. CLIL is a good starting point for teachers and educators to make inquiry happen in the classroom.

\section{Acknowledgments}

This work was supported by JSPS Grant-in-Aid for Scientific Research (C) No. 985910.

Sachiko Yasuda is an Associate Professor in the School of Languages and Communication at Kobe University, Japan. She received her PhD in Second Language Studies from the University of Hawai'i at Mānoa. Her research is in the area of second language writing, systemic functional linguistics, and foreign language pedagogy and assessment through CLIL, task-based language teaching, and genre-based approaches.

\section{References}

Adrián, M. M., \& Mangado, M. J. G. (2009). The acquisition of English syntax by CLIL learners in the Basque country. In Y. Ruiz de Zarobe \& R. M. Jiménez Catalán (Eds.), Content and language integrated learning: Evidence from research in Europe (pp. 176-196). https://doi.org/10.21832/9781847691675-013 
Agustín Llach, M. P., \& Jiménez Catalán, R. M. (2007). Lexical reiteration in EFL young learners' essays: Does it relate to the type of instruction? International Journal of English Studies, 7(2), 85-103.

Bialystok, E. (2001). Metalinguistic aspects of bilingual processing. Annual Review of Applied Linguistics, 21, 169-181. https://doi.org/10.1017/S0267190501000101

Bialystok, E. (2007). Acquisition of literacy in bilingual children: A framework for research. Language Learning, 57, 45-77. https://doi.org/10.1111/j.1467-9922.2007.00412.x

Bialystok, E., Peets, K. F., \& Moreno, S. (2014). Producing bilinguals through immersion education: Development of metalinguistic awareness. Applied Psycholinguistics, 35, 177-191. https://doi.org/10.1017/S0142716412000288

Brown, P. S. (2013). Teaching a medical English CLIL course with vocabulary learning strategies instruction in Japan. The Asian EFL Journal, 15, 275-304. Retrieved from https://www.asian-efl-journal.com/7621/monthly-journals/ teaching-a-medical-english-clil-course-with-vocabulary-learning-strategiesinstruction-in-japan/

Brown, H., \& Bradford, A. (2017). EMI, CLIL, \& CBI: Differing approaches and goals. In P. Clements, A. Krause, \& H. Brown (Eds.), Transformation in language education (pp. 328-334). Tokyo: JALT. Retrieved from https://jalt-publications.org/ node/4/articles/6058-emi-clil-cbi-differing-approaches-and-goals

Cammarata, L. (2016). Foreign language education and the development of inquirydriven language programs: Key challenges and curricular planning strategies. In L. Cammarata (Ed.), Content-based foreign language teaching: Curriculum and pedagogy for developing advanced thinking and literacy skills (pp. 123-146). https://doi.org/10.4324/9780203850497

Cenoz, J., Genesee, F., \& Gorter, D. (2013). Critical analysis of CLIL: Taking stock and looking forward. Applied Linguistics, 35, 243-262. https://doi.org/10.1093/applin/amt011

Clark, G. (2013). Snapshot of a lower secondary CLIL program in Japan. The Asian EFL Journal, 15(4), 382-393. Retrieved from https://www.asian-efl-journal. com/7641/volume-15-issue-4/snapshot-of-a-lower-secondary-clil-program-injapan/

Coyle, D. (2007). Content and language integrated learning: Toward a connected research agenda for CLIL pedagogies. International Journal of Bilingual Education and Bilingualism, 10, 543-562. https://doi.org/10.2167/beb459.0 
Coyle, D., Hood, P., \& Marsh, D. (2010). CLIL: Content and language integrated learning. Cambridge, England: Cambridge University Press.

Dalton-Puffer, C. (2011). Content-and-language integrated learning: From practice to principles. Annual Review of Applied Linguistics, 31, 182-204. https://doi.org/10.1017/S0267190511000092

Dalton-Puffer, C., Nikula, T., \& Smit, U. (2010). Charting policies, premises, and research on content and language integrated learning. In C. Dalton-Puffer, T. Nikula, \& U. Smit (Eds.), Language use and language learning in CLIL classrooms (pp. 1-19). https://doi.org/10.1075/aals.7.01dal

Dalton-Puffer, C., \& Smit, U. (2013). Content and language integrated learning: A research agenda. Language Teaching, 46, 545-559. https://doi.org/10.1017/S0261444813000256

DeKeyser, R. (2007). Practice in a second language: Perspectives from applied linguistics and cognitive psychology. https://doi.org/10.1017/cbo9780511667275

Gajo, L. (2007). Linguistic knowledge and subject knowledge: How does bilingualism contribute to subject development? International Journal of Bilingual Education and Bilingualism, 10, 563-581. https://doi.org/10.2167/beb460.0

García, A. L., \& Whittaker, R. (2010). Writing and speaking in the history class: A comparative analysis of CLIL and first language contexts. In C. Dalton-Puffer, T. Nikula, \& U. Smit (Eds.), Language use and language learning in CLIL classrooms (pp. 126-143). https://doi.org/10.1075/aals.7.07lli

Halliday, M. A. K. (1994). An introduction to functional grammar. London, England: Edward Arnold.

Halliday, M. A. K. (1996). Literacy and linguistics: A functional perspective. In R. Hasan \& G. Williams (Eds.), Literacy in society (pp. 339-376). London, England: Longman.

Halliday, M. A. K. (1998). Things and relations: Regrammaticising experience as technical knowledge. In J. R. Martin \& R. Veel (Eds.), Reading science: Critical and functional perspectives on discourses of science (pp. 185-235). New York, NY: Routledge.

Hermanto, N., Moreno, S., \& Bialystok, E. (2012). Linguistic and metalinguistic outcomes of intense immersion education: How bilingual? International Journal of Bilingual Education and Bilingualism, 15, 131-145. https://doi.org/10.1080/13670050.2011.652591

Hyland, K., \& Hamp-Lyons, L. (2002). EAP: Issues and directions. Journal of English for Academic Purposes, 1, 1-12. https://doi.org/10.1016/S1475-1585(02)00002-4 
Ikeda, M. (2013). Does CLIL work for Japanese secondary school students? Potential for the 'Weak' Version of CLIL. International CLIL Research Journal, 2(1), 31-43. Retrieved from http://www.icrj.eu/21/article3.html

Ikeda, M. (2016). CLIL focus: An interview with Professor Makoto Ikeda (interviewed by L. MacGregor). The Language Teacher, 40(1), 18-21. Retrieved from https://jalt-publications.org/tlt/articles/4965-clil-focus-interview-professormakoto-ikeda

Ikeda, M., Pinner, R., Mehisto, P., \& Marsh, D. (2013). Editorial. International CLIL Research Journal, 2(1), 1-2. Retrieved from https://www.icrj.eu/21/editorial. $\mathrm{html}$

Iyobe, B., \& Li, J. (2013). CLIL to what degree: A trial in English medium education at a Japanese university-Is it CLIL or not? The Asian EFL Journal, 15(4), 372-381. Retrieved from https://www.asian-efl-journal.com/7640/volume15-issue-4/clil-to-what-degree-a-trial-in-english-medium-education-at-ajapanese-university-is-it-clil-or-not/\#squelch-taas-tab-content-0-3

Jaekel, N., Schurig, M., Florian, M., \& Ritter. M. (2017). From early starters to later finishers? A longitudinal study of early foreign language learning in school. Language Learning, 67, 631-664. https://doi.org/10.1111/lang.12242

Jäppinen, A.-N. (2005). Thinking and content learning of mathematics and science as cognitional development in content and language integrated learning (CLIL): Teaching through a foreign language in Finland. Language \& Education, 19, 148-169. https://doi.org/10.1080/09500780508668671

Jexenflicker, S., \& Dalton-Puffer, C. (2010). The CLIL differential: Comparing the writing of CLIL and non-CLIL students in higher colleges of technology. In C. Dalton-Puffer, T. Nikula, \& U. Smit (Eds.), Language use and language learning in CLIL classrooms (pp. 169-189). https://doi.org/10.1075/aals.7.09jex

Kolb, D. A. (1984). Experiential learning: Experience as the source of learning and development (Vol. 1). Englewood Cliffs, NJ: Prentice-Hall.

Llinares, A., Morton, T., \& Whittaker, R. (2012). The roles of language in CLIL. New York, NY: Cambridge University Press.

Lo, Y. Y., \& Murphy, V. A. (2010). Vocabulary knowledge and growth in immersion and regular language learning programmes in Hong Kong. Language \& Education, 24, 215-238. https://doi.org/10.1080/09500780903576125

Long, M. (1996). The role of the linguistic environment in second language acquisition. In W. C. Ritchie \& T. K. Bhatia (Eds.), Handbook of second language acquisition (pp. 413-468). New York, NY: Academic Press. 
Lorenzo, F., Casal, S., Moore, P. (2009). The effects of content and language integrated learning in European education: Key findings from the Andalusian bilingual sections evaluation project. Applied Linguistics, 31, 418-442. https://doi.org/10.1093/applin/amp041

Lyster, R. (2007). Learning and teaching language through content: A counterbalanced approach. Amsterdam, The Netherlands: John Benjamins. https://doi.org/10.1075/1llt.18

MacGregor, L. (2016). CLIL in Japan: University teachers' viewpoints. In P. Clements, A. Krause, \& H. Brown (Eds.), Focus on the learner (pp. 426-432). Tokyo: JALT. Retrieved from http://jalt-publications.org/node/4/articles/5419-clil-japanuniversity-teachers $\% \mathrm{E} 2 \% 80 \% 99$-viewpoints

Marsh, D. (Ed.) (2002). CLIL/EMILE - The European dimension: Actions, trends and foresight potential. Brussels, Belgium: European Commission.

MEXT (2009). Elementary school Course of Study guidelines: Foreign language activities. Retrieved from http://www.mext.go.jp/component/a_menu/education/ micro_detail/_icsFiles/afieldfile/2010/10/20/1261037_12.pdf

Meyer, O., Coyle, D., Halbach, A., Schuck, K., \& Ting, T. (2015). A pluriliteracies approach to content and language integrated learning: Mapping learner progressions in knowledge construction and meaning making. Language Culture and Curriculum, 28, 41-57. https://doi.org/10.1080/07908318.2014.1000924

Moreno, S. (2009). Young learners' L2 word association response in two different learning contexts. In Y. Ruiz de Zarobe \& R. M. Jiménez Catalán (Eds.), Content and language integrated learning: Evidence from research in Europe (pp. 93111). https://doi.org/10.21832/9781847691675

Nikula, T., Dalton-Puffer, C., Llinares, A. \& Lorenzo, F. (2016). More than content and language: The complexity of integration in CLIL and bilingual education. In T. Nikula, E. Dafouz, P. Moore, \& U. Smit (Eds.), Conceptualising integration in CLIL and multilingual education (pp. 1-26). https://doi.org/10.21832/9781783096145-004

Paydon, S. A., Birchley, S. L., \& McCasland, P. L. (2015). Demystifying current trends in language education. In P. Clements, A. Krause, \& H. Brown (Eds.), JALT2014 Conference Proceedings (pp. 34-47). Tokyo: JALT. Retrieved from https:// jalt-publications.org/proceedings/articles/4690-demystifying-current-trendslanguage-education

Roquet, H., \& Pérez-Vidal, C. (2015). Do productive skills improve in content and language integrated learning contexts? The case of writing. Applied Linguistics, 38, 489-511. https://doi.org/10.1093/applin/amv050 
Santos, P. (2013). Learning through in-house videos: How one Japanese college integrates subject content in its EAP program. The Asian EFL Journal, 15(4), 324-329. Retrieved from https://www.asian-efl-journal.com/7626/volume15-issue-4/learning-through-in-house-videos-how-one-japanese-collegeintegrates-subject-content-in-its-eap-program/

Surmont, J., Struys, E., Van den Noort, M., \& Van den Craen, P. (2016). The effects of CLIL on mathematical content learning: A longitudinal study. Studies in Second Language Learning and Teaching, 6, 319-337. https://doi.org/10.14746/ssllt.2016.6.2.7

Takano, N., Kambara, J., Kedoin, E., \& Suzuki, Y. (2016). 小学校英語にCBI/CLILを:メリ ットとコツ [CBI/CLIL for elementary school English: Benefits and tips]. In P. Clements, A. Krause, \& H. Brown (Eds.), Focus on the learner. Tokyo: JALT. Retrieved from https://jalt-publications.org/node/4/articles/5371-cbiclil-elementaryschool-english-benefits-and-tips-・小学校英語にcbiclilを:メリットとコツ

Ting, Y.-L. T. (2010). CLIL appeals to how the brain likes its information: Examples from CLIL-(neuro)science. International CLIL Research Journal, 1(3), 3-18. Retrieved from https://www.icr.eu/13/article1.html

Toh, G. (2013). Towards a critically and dialogically mediated EAP. The Asian EFL Journal, 15(4), 212-230. Retrieved from https://www.asian-efl-journal. com/7615/monthly-journals/towards-a-critically-and-dialogically-mediatedeap/\#squelch-taas-tab-content-0-3

Unterberger, B. (2014). English-medium degree programmes in Austrian tertiary business studies: Policies and programme design (Unpublished doctoral dissertation). University of Vienna, Austria.

Van de Craen, P., Ceuleers, E., \& Mondt, K. (2007). Cognitive development and bilingualism in primary schools: Teaching maths in a CLIL environment. In D. Marsh \& D. Wolff (Eds.), Diverse contexts-Converging goals. CLIL in Europe (pp. 185-200). Frankfurt am Main, Germany: Peter Lang.

Villarreal Olaizola, I., \& García Mayo, M. P. (2009). Tense and agreement morphology in the interlanguage of Basque/Spanish bilinguals. In Y. Ruiz de Zarobe \& R. M. Jiménez Catalán (Eds.), Content and language integrated learning: Evidence from research in Europe (pp. 157-175). https://doi.org/10.21832/9781847691675

Walker, E. (2010). Evaluation of a support intervention for senior secondary school English immersion. System, 38, 50-62. https://doi.org/10.1016/j.system.2009.12.005

Watanabe, Y., Ikeda, M., \& Izumi, S. (Eds.). (2011). CLIL: New challenges in foreign language education (Vol. 1). Tokyo: Sophia University Press. 
Watanabe, Y., Ikeda, M., \& Izumi, S. (Eds.). (2012). CLIL: New challenges in foreign language education (Vol. 2). Tokyo: Sophia University Press.

Wei, R. (2013). Chinese-English bilingual education in China: Model, momentum, and driving forces. The Asian EFL Journal, 15(4), 184-200. Retrieved from https://www.asian-efl-journal.com/7611/monthly-journals/chinese-englishbilingual-education-in-china-model-momentum-and-driving-forces/\#squelchtaas-tab-content- $0-0$

Yamano, Y. (2013a). CLIL in a Japanese primary school: Exploring the potential of CLIL in a Japanese EFL context. International CLIL Research Journal, 2(1), 19-30. Retrieved from https://www.icrj.eu/21/article2.html

Yamano, Y. (2013b). Using the CLIL approach in a Japanese primary school: A comparative study of CLIL and EFL lessons. The Asian EFL Journal, 15(4), 160183. Retrieved from https://www.asian-efl-journal.com/7609/main-journals/ utilizing-the-clil-approach-in-a-japanese-primary-school-a-comparative-studyof-clil-and-efl-lessons/\#squelch-taas-tab-content-0-0

Yang, M., \& Zhang, Z. (2013). Development of academic competencies as the learning objectives of an English-medicine integrated common-core module. The Asian EFL Journal, 15(4), 395-405. Retrieved from https://www.asian-efl-journal.com/7642/volume-15-issue-4/development-of-academic-competenciesas-the-learning-objectives-of-an-english-medicine-integrated-common-coremodule/\#squelch-taas-tab-content-0-3

Yasuda, S. (2017). Towards a framework for linking linguistic knowledge and writing expertise: Interplay between SFL-based genre pedagogy and task-based language teaching. TESOL Quarterly, 51, 576-606.

https://doi.org/10.1002/tesq.383 